\title{
The Nordea Bank Denmark Case (C-48/13)
}

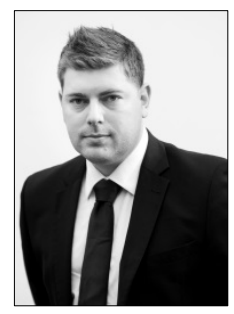

Associate Professor, Phd

Anders Nørgaard Laursen

Department of Law

School of Business and Social Sciences,

Aarhus University

Abstract: This paper reports on an investigation of a recent decision by the European Court of Justice (ECJ) in case C-48/13, Nordea Bank Denmark, concerning the Danish rules for reincorporation of losses from permanent establishments situated in European Union/European Economic Area (EU/EEA) member states other than Denmark. The article includes comments on various EU tax law aspects of the case - namely the restriction test applied by the ECJ, the justifications brought forward by the intervening governments and the question of proportionality - and examines the consequences of the Danish tax law going forward.

\section{Introduction}

On 17 July 2014, the European Court of Justice (ECJ) gave its decision in Nordea Bank Denmark. ${ }^{1}$ This article examines the decision and comments on its various European tax law aspects and the implications of the decision from a Danish point of view. 


\section{Facts}

In the period 1996 to 2000, Nordea Bank Denmark A/S had engaged in retail banking activities in Finland, Sweden, and Norway through permanent establishments in the form of bank branches, which were losing money every year. As a result, a total of DKK 204.402.324 was deducted from the basis of assessment to Danish tax.

In 2000, the activities of those permanent establishments were restructured; their offices were closed, their customers offered the possibility of retaining their accounts on identical terms with subsidiaries of Nordea Bank Denmark in the same states, and half of their staff was absorbed by those subsidiaries or by other local companies in the same group. Because, under Danish tax law, this transaction was analogous to the partial sale of a business, the losses were reincorporated into Nordea Bank Denmark's taxable profit. ${ }^{2}$

According to the Nordea Bank Denmark, the reincorporation of losses was contrary to the Freedom of Establishment, Articles 49 and 54 of the Treaty on the Functioning of the European Union (TFEU) and - because Norway was involved - contrary to Articles 31 and 34 of the European Economic Agreement (EEA). On those grounds, Nordea Bank Denmark contested the reincorporation of losses before the Eastern Regional Court, ${ }^{3}$ which in turn referred the case to the ECJ for a preliminary ruling.

\section{The Decision}

\subsection{The Restriction Test}

The ECJ began, as it often does, by restating the question from the national court:

By its question, the referring court asks, in essence, whether Articles 49 TFEU and 54 TFEU and Articles 31 and 34 of the EEA Agreement preclude legislation of a Member State under which, in the event of transfer by a resident company to a non-resident company in the same group of a permanent establishment situated in another Member State or in another State that is party to the EEA Agreement, the losses previously deducted in respect of the establishment transferred are reincorporated into the transferring company's taxable profit. 4

2 The legal basis for this was the $\S 33 \mathrm{D}$, para. 5 of the Danish Tax Assessment Act (ligningsloven). The provision was abolished in 2005.

3 "Østre Landsret", the second-tier court in Denmark.

4 Nordea Bank Denmark, supra n. 1, p. 16. 
After restating the question at hand, the ECJ reaffirmed its own wellestablished case law: that EU law provide the freedom for companies or firms formed in accordance with the law of a member state to exercise their activity in another member state through a subsidiary, a branch or an agency. It also held that whilst the provisions of the TFEU concerning freedom of establishment are directed at ensuring that foreign nationals and companies are treated in the host member state in the same way as nationals of other states, they also prohibit the member state of origin from hindering the establishment in another member state of a company incorporated under its legislation particularly through a permanent establishment.

Following these initial statements, the ECJ turned to the question of whether the Danish rules restricted freedom of establishment.

First, the ECJ settled an obvious issue: the fact that offsetting losses incurred by a permanent establishment situated in another member state against profits and taxable income of the principal company constitutes a tax advantage. The provisions at issue in Nordea Bank Denmark resulted in an advantage being denied to Danish companies with permanent establishments abroad - advantages that were not denied to Danish companies with permanent establishments only in Denmark. They established a rule requiring the reincorporation of losses lawfully deducted, in respect of the foreign establishments transferred - a rule that does not apply if establishments in Denmark are transferred under identical circumstances. Such disadvantageous treatment is liable to deter a Danish company from conducting business through a permanent establishment situated in a member state. The ECJ found, therefore, that the provision at hand constituted a restriction prohibited in principle by EU law.

The ECJ concluded that a Danish company with a permanent establishment in another member state is not in a situation objectively comparable to that of a Danish company with only Danish permanent establishments in relation to measures laid down in order to prevent or mitigate the double taxation of a resident company's profits. By making the profits of permanent establishments situated in Finland, Sweden and Norway subject to Danish tax, however, Denmark had equated those establishments with resident permanent establishments so far as it concerns the deduction of losses.

Although these findings regarding comparability and restrictions may come as no surprise in light of previous case law of the ECJ, it is notable that the ECJ uses the term "a restriction prohibited in principle". 5 
Why does the ECJ find a restriction only in principle? The answer lies in the following paragraph:

It is clear from the Court's case-law that such a restriction is permissible only if it relates to situations which are not objectively comparable or if it is justified by an overriding reason in the public interest. ${ }^{6}$

Although the ECJ would not separate the restriction test from the comparability test when testing national tax provisions against the fundamental freedoms in older case law, ${ }^{7}$ this seems to be the case in recent case law, however, ${ }^{8}$ as further confirmed by Nordea Bank Denmark.

That the restriction test is separate from the comparability test seems to imply that the ECJ has become aware of the debate concerning so-called non-discriminatory restrictions. Some scholars argue that if a national tax provision hinders fundamental freedoms, this issue can be resolved only by reference to overriding reasons in the public interest - that there is no need to examine whether different treatment was applied in comparable situations. ${ }^{9}$ This argument is in line with application of the so-called Gebhard Test, applied by the ECJ in other non-tax cases. According to the Gebhard Test, only restrictions applied in a non-discriminatory matter can be justified by overriding reasons in the public interest. 10

This situation has never existed in case law concerning direct taxation, however. The ECJ always examines whether the national tax provision indeed entails differential treatment of objectively comparable situations. Only if it can be established that differential treatment has been applied, does the ECJ look for overriding reasons in the public interest. If, on the other hand, there is no differential treatment of objectively comparable situations, the ECJ will conclude, on those grounds alone, that there is no breach of EU law. ${ }^{11}$

When the ECJ in Nordea Bank Denmark explicitly states the permissibility of a restriction related to situations that are not objectively comparable, the argument that the ECJ will find non-discriminatory restrictions to be in breach of EU Law in direct tax cases seems to be viable only de lege ferenda.

6 Nordea Bank Denmark, supra n. 1, p. 23.

7 See inter alia case C-446/03, Marks \& Spencer II, p. 32-33.

8 See inter alia case C-337/08, X holding, p. 20, and case C-18/11, Philips Electronics, p. 17.

9 See inter alia Sjoerd Douma, Non-discriminatory Tax Obstacles (2012) 21 EC Tax Review, issue 2, pp. 67-83.

10 Case C-55/94, Reinhard Gebhard, p. 37.

11 See inter alia case C-298/05, Columbus Container Services. 


\subsection{Overriding Reasons in the Public Interest}

From the opinion of the Advocate General (AG), it becomes clear that the intervening member states had relied on three justifications previously recognized by case law of the ECJ: (1) preservation of the allocation of the power to impose taxes between member states, (2) preservation of the coherence of a tax system and (3) prevention of tax avoidance. The ECJ, however, applied the justifications in a slightly different manner, citing only the views of the Danish government: that the restriction was needed to ensure a balanced allocation of the power to impose taxes between member states in connection with the prevention of tax avoidance. ${ }^{12}$

It was clear from the explanatory memorandum to the provision being tested that the rule requiring the reincorporation of losses deducted in respect of foreign permanent establishments:

has the purpose of preventing, for example, Danish companies from making deductions for losses in foreign branches, and subsequently, when the branch begins to generate a profit, selling it to an affiliated foreign company, so that actual reincorporation of the losses in Denmark is impossible. ${ }^{13}$

In the eyes of the ECJ, this purpose could justify the restriction.

If Denmark were denied the power to reincorporate the previously deducted losses into the taxable profit of the Danish company transferring the permanent establishments, and given that it had lost the power to tax any future profits, the arrangement would artificially erode its tax base. This situation would, in turn, affect the allocation of Denmark's power to impose taxes resulting from the Nordic Double Tax Convention.

Although these finding may not be controversial, they are certainly interesting in light of the AG's opinion.

The preservation of the allocation of taxing rights between member states has become the argument of choice for member states in recent years when they are trying to justify restrictive national tax provisions before the ECJ. ${ }^{14}$ In the AG's opinion, the ground of justification called "preservation of the allocation of the power to impose taxes between Member States" is simply an expression of other recognised grounds of justification, specifically with regard to the delimitation of the fiscal sovereignty of member states. ${ }^{15}$

12 Nordea Bank Denmark, supra n. 1, p. 26.

13 Nordea Bank Denmark, supra n. 1, p. 28.

14 See inter alia Marks \& Spencer II, supra n. 7; C-231/05, Oy AA; C-414/06, Lidl Belgium; X holding, supra n. 8; C-371/10, National Grid Indus and Philips Electronics, supra n. 8.

15 See opinion of GA Kokott in Nordea Bank Denmark, supra n. 1, p. 42. 
The Danish government had argued that reincorporation of losses occurred only when the permanent establishments were transferred to other companies in the group. Denmark could no longer exercise taxing rights over profits earned by the former permanent establishments post transfer. Although the AG was not dismissive of the argument as such, she did find that the idea of profits and losses arising from an activity not be taken into account separately is simply a question of preserving the coherence of a tax system. This reasoning also seemed to be in line with the ECJ's decision in Krankenheim ${ }^{16}$.

The AG then addressed the ECJ directly:

It is in the interests of the clarity of case-law, however, if, when it comes to examining the justification for a restriction on the fundamental freedoms, the actual ground is brought to the fore rather than being concealed behind the label of "allocation of the power to impose taxes". ${ }^{17}$

Given her views, the AG examined the arguments advanced by the intervening governments subsumed under the concept of "preservation of the allocation of the power to impose taxes between Member States", as "preservation of the coherence of a tax system".

The ECJ did not follow the AG on this point. As mentioned previously, the ECJ found the restriction to be justified on two grounds: (1) preservation of the allocation of taxing rights between the member state and (2) the prevention of tax avoidance. It is noteworthy, however, that the ECJ's line of reasoning concerning the allocation of taxing rights between member states seems to follow the arguments advanced by the GA behind the label 'preservation of the coherence of the tax system'. This consistency seems to imply that the two justifications do indeed have a common scope, but that the ECJ recognizes this common scope only in the allocation of taxing rights.

\subsection{Proportionality}

As the ECJ found that the restriction could be justified, it tested whether the legislation went beyond what was necessary to attain its objective, and found that it did.

The ECJ stated that the objective of the balanced allocation of the power to impose taxes is to safeguard the symmetry between the right to tax profits and the right to deduct losses. The need to safeguard that symmetry means that the losses deducted in respect of the permanent establishment must be capable of being offset by taxation of

16 See case C-157/07, Krankenheim Ruhesitz am Wannsee-Seniorenheimstatt, p. $42-43$.

17 See opinion of GA Kokott in Nordea Bank Denmark, supra n. 1, p. 46. 
its profits under the tax jurisdiction of the member state in question. That includes both the taxation of profits made throughout the period when the permanent establishment belonged to Nordea Bank Denmark and those made when the permanent establishment was transferred. It was undisputed that Denmark could, indeed, tax these profits and that the transfer of assets of the permanent establishments within the group had to be valued at arm's length.

Based on these findings, that ECJ concluded that:

[...] a provision of a Member State, [...] which provides, in the event that a resident company transfers to a non-resident company in the same group a permanent establishment situated in another Member State or in another State that is party to the EEA Agreement, for the reincorporation of the losses previously deducted in respect of the establishment transferred goes beyond what is necessary to attain the objective relating to the need to safeguard the balanced allocation of the power to impose taxes if the first Member State taxes the profits made in respect of that establishment before its transfer, including those resulting from the gain made upon the transfer. ${ }^{18}$

The conclusion entails that it is not prohibited to reincorporate previously deducted losses from permanent establishments situated in other EU member states or EEA member states. It is legal, however, to reincorporate losses only if they correspond to (1) profits made while the permanent establishment was part of Nordea Bank Denmark and (2) profit resulting from transfer of the permanent establishments. Any excess from previously deducted losses cannot be reincorporated.

Although this solution may seem Solomonic, it does not really solve the problem for the member states. The ECJ had accepted the fact that the objective of the Danish legislation was to avoid the risk of tax avoidance by a group organizing its business such that it deducts from its taxable income in Denmark the losses incurred by a lossmaking permanent establishment situated in Finland, Sweden or Norway. Once that establishment has become profitable, the group could then transfer the establishment's business to a company that it controls - a company that is liable to tax in Finland, Sweden or Norway, but not in Denmark. An obvious part of the setup, which the Danish rules tried to prevent, was that the permanent establishments do not turn a profit until they are transferred. ${ }^{19}$ Hence, the actual result from the ECJ's decision seems to entail that reincorporation of

18 Nordea Bank Denmark, supra n. 1, p. 36.

19 One could further argue that even if there were any profit, it would due to the credit imputation system in Article 25 of the Nordic Double Tax Convention, and would not result in any - or only a small amount - of taxes being payable in Denmark. 
previously deducted losses can be offset only against the liquidation proceeds resulting from the transfer of the establishment.

\section{Consequences from a Danish Point of View}

\subsection{Reopening Tax Assessments}

An obvious consequence of Nordea Bank Denmark is that the rules in question, $\S 33 \mathrm{D}$, para. 5, of the Danish Tax Assessment Act (ligningsloven), are noncompliant with EU law. This poses no immediate problem for the Danish government, however, as the provision was abolished in 2005.

On the other hand, the decision offers an opportunity for Danish companies that have had losses reincorporated according to the rules disallowed by the ECJ. Under Danish Tax law, taxpayers can have their tax assessment reopened if a practice of the tax authorities has been overturned by a court decision. Nordea Bank Denmark had its losses reincorporated in 2000; hence under Danish tax law, taxpayers that have been taxed under similar circumstances in any year after 2000 can have their tax assessments reopened. This opportunity is curtailed by statute of limitations, however, which is ten years under Danish Tax law.

Under Danish tax law, the tax authorities are ex officio obligated to issue a resumption circular when previous practice has been overturned. Furthermore, the tax authorities are - also ex officio - obligated to reopen tax assessments for the affected taxpayers.

As mentioned previously, rules under scrutiny in Nordea Bank Denmark were abolished in 2005, when the Danish government passed new legislation on group taxation. The rules still exist transitionally for companies that had deducted losses from foreign permanent establishments before 2005, however, but had chosen not to be taxed under the new optional international group taxation scheme. Thus Nordea Bank Denmark not only overturned the abolished provision in $\S$ $33 \mathrm{D}$, para. 5, of the Tax Assessment Act, but also abolished the transitional rule passed in 2005.

\subsection{International Group Taxation}

Nordea Bank Denmark raised another interesting - and potentially farreaching - issue: how the decision affects the international group taxation regime in the Corporate Tax Act (selskabsskatteloven) § $31 \mathrm{~A}$, para. 11. Under Danish tax law, a group comprising Danish and foreign companies may opt for the international group taxation regime. If the group choses to do so, all companies in the group - both parent companies and subsidiaries of Danish companies - become part of the 
group taxation scheme for a minimum of ten years. If the group opts out of the group taxation scheme before the end of the ten-year minimum term, previously deducted losses from foreign group companies are reincorporated and taxed in the hands of the Danish company chosen to administer the group taxation scheme. This reincorporation of losses essentially corresponds to the rules that applied to foreign permanent establishments in Nordea Bank Denmark. One cannot help but wonder, therefore, if these rules, which were established specifically for international groups, are in breach of EU law as well.

Alas, this is not an easy question to answer, and must be subject to thorough analysis. Although this paper is not the place for such an indepth analysis, the issue does require a few comments.

There is little doubt that the rules constitute a restriction of the freedom of establishment under Articles 49 and 54 TFEU. Reincorporation of losses is a disadvantage applicable only to international groups - never to groups comprising only Danish resident companies. But are international groups and purely domestic Danish groups in an objectively comparable situation regarding the reincorporation of losses? Although they are, in fact, comparable, a purely Danish group of companies cannot opt out the group taxation scheme. Under Danish tax law, all Danish companies that are part of the same group are subject to the mandatory group taxation regime. Hence, the question of having previously deducted losses reincorporated never arises. On those grounds, one could argue that the situation for a purely domestic Danish group is not objectively comparable to an international group, and is therefore not prohibited under EU law to treat them differently.

If the ECJ would consider purely Danish groups and international groups to be in an objectively comparable situation, the Danish rules could be justified by only one or more overriding reasons in the public interest. Undoubtedly, the Danish government would argue, precisely as it did in Nordea Bank Denmark, that the rules are necessary in order to preserve the allocation of power to impose taxes between member states and to prevent tax avoidance. As the rule in the Corporate Tax Act $\& 31 \mathrm{~A}$, para. 11 serves essentially the same purpose as the provision dealt with by the ECJ in Nordea Bank Denmark, it seems reasonable to assume that the ECJ will acknowledge this as a justification.

Assuming this hypothetical situation to be true, this leads one to consider whether the Danish rule goes beyond that which is necessary to obtain its purpose. Again, if one were to compare this situation with that of Nordea Bank Denmark, then the answer is clearly yes: The Danish rules go further than necessary. One must distinguish between the two situations, however. Nordea Bank Denmark is concerned with the transfer of permanent establishments situated in other member 
states or EEA member states, whereas the Danish group taxation rules regard parent companies and subsidiaries as situated in other member states. Therein lies a key difference, because foreign companies, as opposed to foreign permanent establishments, continue to exist after the group has opted out of the group taxation scheme. Thus losses may be carried forward under the rules applicable under the domestic law of their resident state, which could leave the door open for the double utilization of losses - what is known as "double dipping". It is already well-established case law from the ECJ that member states are entitled to safeguard against tax avoidance of this type. ${ }^{20}$

\section{Concluding Remarks and Recapitulation of Findings}

With its decision in Nordea Bank Denmark, the ECJ has found the Danish rules concerning reincorporation of previously deducted foreign losses to be in breach of the fundamental freedoms of Articles 49 and 54 TFEU and Articles 31 and 34 EEA. That decision confirms the recent trend of the ECJ when testing if national tax provisions constitute a restriction of the fundamental freedoms of the TFEU. When testing such provisions, the ECJ will initially establish if a restriction exists; in the words of the ECJ, it is, in principle, prohibited under EU law. Then the ECJ goes on to examine whether the restriction is tantamount to different treatment of objectively comparable situation. Only if this situation proves to be the true, apparently, will the ECJ find a restriction prohibited not only in principle but also by law. By this reasoning, there seems little doubt that the ECJ will find a national tax provision to be contrary to EU law only if it offers differential treatment in objectively comparable situations. Thus non-discriminatory restrictions are permissible in the eyes of the ECJ.

The decision also offers guidance on the interpretation of some overriding reasons in the public interest that have been accepted as justification for restrictive national tax provisions. In the eyes of the AG, an argument in which profits and losses must be treated within the same tax system pertains to the need to preserve a coherent tax system. The ECJ, however, treated this as an argument pertaining to the balanced allocation of taxing rights between member states. It seems, therefore, that the content of the justifying reason known as the "need to preserve a coherent tax system" has been absorbed by the argument of "a balanced allocation of taxing rights between member 
states", leaving it highly doubtful whether the former argument still has any real scope.

Regarding the issue of proportionality, the ECJ concluded in Nordea Bank Denmark that it is permissible to reincorporate previously deducted losses from a permanent establishment situated in another member state. Reincorporation is permissible, however, only in so far as it corresponds to profits made in respect of that establishment before its transfer, including those resulting from the gain made upon the transfer. Although this solution may appear to be a fair and logical one, it does not really solve the problem for the member states. The purpose of the Danish provision in the case was to avoid the risk of tax avoidance by a resident company conducting its business abroad through a permanent establishment, only while the business abroad was incurring losses that could be offset against the taxable income of the company in its Danish tax assessment. If the business were to become profitable, the permanent establishment would be transferred to another group company, rendering the profit non-taxable in Denmark. An obvious part of the setup is that the business conducted in another member state generates no taxable income; thus the actual result from the ECJ's decision is that reincorporation of previously deducted losses can be offset only against the liquidation proceeds resulting from the transfer of the establishment.

From the point of view of Danish tax law, the decision poses no immediate problem for the Danish government, as the provision at the centre of the case was abolished in 2005. Other companies that have had foreign losses reincorporated according to the same provision, however, can have their tax assessments reopened. The Danish tax authorities are expected to issue an official guideline concerning the issue.

Even though the provision was abolished in 2005, a similar set of transitional rules has been in place ever since. Because of Nordea Bank Denmark, these rules must now be seen now as contrary to EU law.

A final possible consequence of Nordea Bank Denmark is the questions that can be raised about part of the Danish international group taxation regime being consistent with EU law. If an international group opts for the Danish international group taxation scheme, this choice is binding for ten years. If the group wants out before the end of that period, any loss deducted by foreign companies - parent companies as well as subsidiaries - during the period in which the group taxation scheme was effective are reincorporated and taxed in the hands of the Danish company administering the scheme. The rules are analogues to the provisions tested by the ECJ in Nordea Bank Denmark; hence an argument could be made that, consequently, these rules are also in breach of EU law. As Nordea Bank Denmark dealt with the rein- 
corporation of losses from permanent establishments, however, the rules regarding the international group taxation regime concern foreign parent companies and subsidiaries. Bearing in mind the fundamental difference between the tax treatment of a permanent establishment and the tax treatment of a group company under an international group taxation scheme, the ECJ will not necessarily assess the two sets of rules for reincorporation of losses in the same way. 